\title{
Death Drive In Psychoanalysis versus Existential Psychotherapy
}

\author{
Pari Tirsahar* \\ University of Tutor, UK \\ Submission: November 15, 2017; Published: December 05, 2017 \\ *Corresponding author: Pari Tirsahar, University of Tutor, London, UK, Email: paria.kiarash@yahoo.com
}

\section{Introduction}

In Greek myth, the demon of death was the son of Nix (god of the night) and Erebus (god of darkness) and a twin to Hypnos (sleep). The term 'death drive' was coined by Freud for the first time 1920 in Beyond the Pleasure Principle, according to which 'Thanatos' is posited opposite of Eros, the creative and productive drives, sexuality and survival. In classic psychoanalytic theory the death drive (Thanatos) is seen as a drive towards selfdestruction and death. The death drive forces mankind into risky and self-destructive behaviors that could lead to death S Freud [1]. The death drive can be related to the work of the German philosopher Arthur Schopenhauer who in his book The World as Will and Representation by Schopenhauer A [2] says that we all exist by the will to live which is affirmed by pleasure. But he believed that life is a source of suffering and pain Heidegger [3]. Analysis of death is focusing on the existential significance and wants to understand the death phenomenon.

We need to understand and see Dasein as a whole, as a possibility. Dasein sees death as something inevitable but something that is happening to others and not to him. Therefore the concept of death is something that Dasein doesn't connect with the I Jasper, however, views Dasein as a way of being who, despite being part of existence is nevertheless impossible to understand merely as an isolated individual. According to Jaspers [4] human beings are aware that their future death is inevitable, but since they cannot experience their own death they do not perceive death as something to be concerned about. Others may hide from its existence by viewing it as belonging to some magical or nihilistic dimension. I choose to discuss the death drive in the context of psychoanalysis and existential psychotherapy.

\section{Beyond the pleasure}

In his book Project for a Scientific Psychology by S Freud [5] says that all mankind's mental events are directed and regulated by id which is the biggest part of the human mind and makes people to desire pleasure and avoid pain at any cost.
In Civilisation and Its Discontents by $S$ Freud [6] says that the pleasure principle determines the purpose of life thus being analogous to the reality principle. But then Freud realized that there were three conflicting facts in the human mind that he could not explain with the pleasure principle, and that led him to another principle which he found beyond the pleasure principle, and this in turn led him to the concept that later became known as the death drive.

The first conflicting problem Freud was confronted with was the paradox of PTSD in working with traumatized soldiers who had participated in World War I. He observed that they had this tendency to repeat or illustrate their traumatic experiences in a way that brought them back to the combat scene, and this contradicted Freud's pleasure principle or other people with odd behaviours that were engaged repeatedly in behaviours in which there is hard to find any source of pleasure

Another exception was discovered when Freud observed children's games e.g. when his grandson staged his mother's disappearance or when other children threw their toys away. This made Freud wonder how repetition of these distressing experiences would fit within the pleasure principle.

The repletion compulsion was the third exception. Freud had noticed in his practice that his patients when dealing with very distressing and painful life events would repress these experiences, but then they regularly felt compelled to repeat them, not as a memory from the past but as a current experience. The repetition compulsion in Freud's eyes was a primitive instinct.

To seek other explanations for this destructive drive Freud revised his previous views on masochism which he had viewed as a consequence of traumatic childhood experiences. In The Ego and the Id by S Freud [7] he argues that the death drive expresses itself partially through destruction which is directed against the world. A year later he was more clear in his explanations and said that the libido's function is to make the destructive drive 
innocent by redirecting it outwards. The drive at this point was called the destructive drive, the drive for superiority, or the will power.

At the end of the decade in Civilization and Its Discontents he finally admitted that these new views had attained such a great hold upon him that he no longer could think in any other way. From a philosophical viewpoint the death instinct can be related to the German philosopher Schopenhauer's work. In his book The World as Will and Representation he said that all mankind exist by metaphysical powers, namely the 'Will' and that pleasure maintain this drive. But since he was a pessimist he believed that this confirmation of the will to live was an unfavorable and unethical thing, as he believed that life produces more pain than pleasure and bliss. The death instinct is a manifestation of an essential and common antithesis of the will power [8].

\section{Heidegger's Analysis of Death}

Heidegger's definition of death is not focusing upon people's feelings when they are at the death stage nor is he concerned with death as a biological phenomenon. By facing death the meaning of being is defined and clear for 'Dasein'. In Heidegger's view there are two ways of being: authentic and inauthentic. Heidegger does not give an explanation for death itself but offers a phenomenology of our relationship to death. Even though his philosophy is thoughtful it is also gloomy. His account of death portrays a no-hope mode of being, and he has often been criticized for this [3]. Analysis of death is focusing on the existential significance and wants to understand the death phenomenon. We need to understand and see 'Dasein'as a whole, as a possibility. 'Dasein'sees death as something inevitable but something that is happening to others and not to himself. Therefore the concept of death is something that 'Dasein'doesn't connect with the 'I'.

'Dasein' understands the reality of death as an ever happening phenomenon in the world but it only happens to others and it has nothing to do with me and thus death continues to live unbeknownst to all and with no contact with the 'I'. When 'Dasein'faces his own death then that is a completely different phenomenon than facing other's death. The fact that I die means the end of my potential, the end of my world. According to Heidegger the fear of my own death is in essence the fear of my extinction as a human being. This causes me a great deal of anxiety. I may be able to face other people's death but may find it virtually impossible to come to terms with my own. 'Dasein'cannot experience its own death. As long as 'Dasein exists, it is not complete, that is, there are still some of its possibilities outstanding. If, however, 'Dasein'dies, then it is 'nolonger there'.

\section{Jaspers' Analysis of Death}

Jaspers [4] Talks about the opportunity for 'Existenz'to the final phenomena, which is Transcendence, which is neither eternity nor total eradication. Even though Jaspers' notion of death is not religious, he nevertheless uses some existential terms i.e. 'Existenz', Transcendence and Being that usually have religious connotation but under a different phraseology.

According to Dasein is a mode of being which manifests itself as the empirical self with a temporal dimension. It is a part of the world but cannot be understood as an object in isolation. 'Existenz', however, is the true mode of being this is an inevitable condition of man's existence. Moreover, there are four major 'boundary situations' (those situations which threaten our sense of security and the foundation of our existence) of which the most important one is death because it signifies the end of man's world.

According to human beings are aware that their future death is inevitable, but since they cannot experience their own death they do not perceive death as something to be concerned about. Others may hide from its existence by viewing it as belonging to some magical or nihilistic dimension Jaspers [3].

According to Jaspers [4] death has two different meanings. Death is perceived as either the cessation of existence as an objective fact, or as a specific boundary situation. Facing one's own death is a specific boundary situation and it is personal because Existenz convinces itself that Dasein- the basis of its empirical existence, i.e. the bodily existence - is temporal and transient and has to come to an end. Unlike the end of one's empirical being, Existenz itself is not subject to death. As Existenz we are concerned with the significance of death and how we relate to it. We know that we have to face up to nothingness as there is no return for 'Dasein'and we will have to come to terms with this [4] says when we lose someone we love then life becomes an isolated existence for us, and as result of agony and bereavement we feel hopeless which could lead us to the pain and boundary situation of death. Even though death annihilates the person we love, the existential connection is intact and infinite. Based on man can understand the undeniable truth of his future death and the notion of annihilation.

Man believes that as long as he is alive he cannot experience his own death, and once he ceases to be alive he cannot experience it either - a typical Epicurean argument! So, the experience of one's own death does not seem possible. As a result, he does not perceive death as a reason for concern. He ignores his possible Existenz and clings on to his worldly activities. Alternatively, Dasein may ignore its everyday existence entirely and hide within its nihilistic or mystical realms. This would be another way of avoiding boundary situations. Thus, if man cannot face up to death existentially, he either preoccupies himself with worldly things or escapes into the mystical realms.

\section{References}

1. Freud S (1987) Beyond the Pleasure Principle. 5: Vienna, London.

2. Schopenhauer A (2008) The World as Will and Presentation. Longman, New York, USA.

3. Heidegger (1927) Being and Time. Harper, New York, USA. 
4. Jaspers K (1971) Philosophy of Existence. ( $5^{\text {th }}$ edn.) University of Pennsylvania, Pennsylvania, USA.

5. Freud S (1895) A Project for Scientific Psychology unfinished manuscript in The Origins of Psychoanalysis. Letters to Wilhelm Flies, Drafts, and Notes 1887-1902 Basic Books, 1977. pp 345-445.
6. Freud S (1930) Civilization and Its Discontents ( $3^{\text {rd }}$ edn.) Wien: Internationaler Psychoanalytischer Verlag.

7. Freud S (1897) The Ego and the Id ( $3^{\text {rd }}$ edn.) Harper, New York, USA.

8. Freud S (1922) The Economic Problem of Masochism. Vienna, London.
This work is licensed under Creative Commons Attribution 4.0 License

DOI: 10.19080/PBSIJ.2017.08.555726

\section{Your next submission with Juniper Publishers} will reach you the below assets

- Quality Editorial service

- Swift Peer Review

- Reprints availability

- E-prints Service

- Manuscript Podcast for convenient understanding

- Global attainment for your research

- Manuscript accessibility in different formats ( Pdf, E-pub, Full Text, Audio)

- Unceasing customer service

Track the below URL for one-step submission https://juniperpublishers.com/online-submission.php 